\title{
SURFACE PROPERTIES OF BAMBOO AND SCOTS PINE IMPREGNATED WITH BORON AND COPPER BASED WOOD PRESERVATIVES AFTER ACCELERATED WEATHERING
}

\author{
Ergun Baysal ${ }^{1, \$}$, Eylem D. Tomak ${ }^{2}$,Elif Topaloglu ${ }^{3}$ Emrah Pesman ${ }^{4}$
}

\begin{abstract}
In this study, we investigated the color, gloss and surface roughness of bamboo (Phyllostachys bambusoides) and Scots pine (Pinus sylvestris) samples impregnated with boron and copper based preservatives during accelerated weathering from $168 \mathrm{~h}$ to $672 \mathrm{~h}$. Tanalith-E, ACQ, wolmanit-CB were used as copper-based chemicals, while a mixture of boric acid and borax $(7: 3 ; \mathrm{w} / \mathrm{w})$ was used as the boron compound.

Results showed that retention values of bamboo samples were lower than the retention values of Scots pine samples probably due to the bamboo's anatomical structure and penetration characteristic. Bamboo surfaces became rougher and darker after impregnation and accelerated weathering compared to initial surfaces. Longer accelerated weathering periods seemed to have not a considerable effect on surface roughness of bamboo samples impregnated with copper based preservatives. Gloss of impregnated Scots pine samples increased with longer accelerated weathering period while gloss of bamboo samples decreased slightly with longer accelerated weathering period. Wolmanit-CB seemed to be most effective wood preservative for hindering color change and ensuring smooth surfaces after accelerated weathering. Color changes caused by accelerated weathering tended to be greater for impregnated bamboo samples than impregnated Scots pine samples.
\end{abstract}

Keywords: Accelerated weathering, bamboo, boron compounds, color, copper based preservatives, gloss, surface roughness.

\section{INTRODUCTION}

Bamboo is used in many applications such as furniture, crafts, decoration and construction. Untreated bamboo for structural purposes has service life of 2-3 years (Lifang et al. 2010) because it is easily degraded by decay fungi, mould fungi and insects (Salim et al. 2008, Sun et al. 2012, de Melo et al. 2015). Therefore, it is necessary to impregnate bamboo with preservatives to improve its service life. Treatment of bamboo can be applied by the boucherie process, a modified boucherie process, sapdisplacement, diffusion process, ponding, osmo paste diffusion, steaming, quenching, steeping, open tank process and pressure process (Kumar 2007). Treatment with copper chromium arsenate (CCA) and amine copper quat (ACQ) against decay fungi attack (Wahab et al. 2010), treatment with copper based preservative treatment against decay and termite attack in the field test (Jiang 2008), treatment with chitosan-copper complex (CCC), propiconazole (PPA) and tebuconazole (TBA) against mould fungi attack (Sun et al. 2012), and oil heat treatment against termite attack (Manalo and Garcia 2012) and fungal attack (Leithoff and Peek 2001) were investigated to enhance durability of bamboo.

\footnotetext{
${ }^{1}$ Department of Wood Science and Technology, Faculty of Technology, Mugla Sitki Kocman University, Mugla, Turkey.

${ }^{2}$ Forest Industry Engineering Department, Faculty of Forestry, Bursa Technical University, Bursa, Turkey.

${ }^{3}$ Department of Architecture and Urban Planning, Technical Science Vocational School, Giresun University, Giresun, Turkey.

${ }^{4}$ Forest Industry Engineering Department, Faculty of Forestry, Artvin Coruh University, Artvin, Turkey.

"Corresponding author: ergun69@yahoo.com

Received: 10.06.2015 Accepted: 17.12.2015
} 
Outdoor conditions can degrade wood components (Yalinkilic et al. 1999). UV component of sunlight, seasonal changes in relative humidity $(\mathrm{RH})$ and temperature, atmospheric pollution, oxygen, and human activities contribute to the degradation of wood surfaces (Williams 2005). Changes in chemical, physical and optical properties of wood lead to discoloration, loss of gloss, roughening of surface, and are also accompanied by alteration of mechanical properties of the three main wood components (Denes and Young 1999). Wood preservatives formulated by chromium and/or copper compounds can retard weathering and photodegradation of wood components (Feist and Hon 1984, Evans et al. 2005, Temiz et al. 2005, Williams 2005). Feist and Williams (1991) reported that small amounts of chromium salts on the wood surface greatly decrease weathering (erosion) of the wood caused by ultraviolet-light-catalyzed degradation. However, in the recent years, there is a growing environmental concern on the use of heavy duty wood preservatives due to their toxicity effect on the environment and mammalian, therefore, copper based preservatives and boron compounds have gained wide popularity in wood preservation industry (Freeman and McIntyre 2008, Temiz et al. 2014). Increased durability of wood treated with alkylammonium compounds (AACs), copper ethanolamine (Cu-EA), ammoniacal copper quat, copper-azole, tanalith-E 3491 and wolmanit CX-8 against weathering factors was reported by many researchers (Jin et al. 1991, Cornfield et al. 1994, Zhang and Kamdem 2000, Temiz et al. 2005, Nejad and Cooper 2011).

Similar to wood, surface of bamboo is susceptible to degradation, and it loses its color and gloss when exposed to irradiation (Wang and Ren 2008, 2009, Qin and Yu 2009). Natural weathering factors cause bamboo to become lighter in color, and cause lignin and carbohydrate degradations (Kim et al. 2008). The accelerated weathering performance of commonly used copper based preservatives on bamboo is mostly unknown. In this study, color, gloss and surface roughness of bamboo samples impregnated with tanalith-E, wolmanit-CB, ACQ and mixture of boric acid and borax were investigated during weathering from $168 \mathrm{~h}$ to $672 \mathrm{~h}$, and the performance of bamboo samples was compared to the performance of Scots pine which is one of the widely used wood species in Europe.

\section{MATERIALS AND METHODS}

\section{Preparation of samples and preservative solutions}

Bamboo (Phyllostachys bambusoides Sieb. et. Zucc.) culms and Scots pine (Pinus sylvestris L.) sapwood were obtained from Trabzon located in the North-East Black Sea region of Turkey. Culms having bottom diameters of $45 \mathrm{~mm}$, top diameters of $30 \mathrm{~mm}$ and length of $8-9 \mathrm{~m}$ were selected as described in detail by Tomak et al. (2012). Bottom diameters of culms were chosen for the study since the samples having the maximum wall thickness were needed for the measurements. In the study, node sections of the culms were removed because the nodes have a complex structure and decrease mechanical properties (Tomak et al. 2012). Bamboo samples without node section were cut into dimensions of $12 \mathrm{~mm}$ in width, $300 \mathrm{~mm}$ in length and $4 \mathrm{~mm}$ in depth. The density of bamboo and Scots pine samples is $0,80 \mathrm{~g} / \mathrm{cm}^{3}$ and $0,47 \mathrm{~g} / \mathrm{cm}^{3}$; respectively. For comparison purposes, Scots pine (Pinus sylvestris L.) sapwood samples which had the same dimensions as the bamboo samples were used. The dimensions of Scots pine samples were $4 \times 12 \times 300 \mathrm{~mm}$ (R, T, L). Samples were then conditioned at $20{ }^{\circ} \mathrm{C}$ and $65 \%$ relative humidity for four weeks before impregnation process. Wolmanit-CB (CCB), tanalith-E (Tan-E), amine copper quat-1900 (ACQ) and boric acid-borax (BB) were obtained from Emsan Company, Hemel Company, Toktas Impregnation Company and Natural Boron Research Institute (BOREN) in Turkey, respectively. Aqueous solutions of 3\% wood preservatives were prepared using distilled water at a room temperature. In the solution of BB, the ratio of BA to BX was $7 / 3(\mathrm{w} / \mathrm{w})$. Six replicate bamboo and Scots pine samples were used for each treatment. 


\section{Impregnation process}

The samples were first vacuum impregnated with the solutions at $600 \mathrm{~mm} / \mathrm{Hg}$ for $30 \mathrm{~min}$ and then they were immersed in the solutions for $60 \mathrm{~min}$ at atmospheric pressure. Samples were weighted for the retention determinations $\left(R\right.$ in $\left.\mathrm{kg} / \mathrm{m}^{3}\right)$ after removing any excess solution from the surfaces. Then, samples were wrapped in plastic bags for one week at the room conditions to complete the fixation of copper based preservatives into samples. Samples were conditioned again at $20^{\circ} \mathrm{C}$ and $65 \%$ relative humidity for three weeks. The following equation was used to calculate the retentions.

$$
\text { Retention }\left(\frac{\mathrm{kg}}{\mathrm{m}^{3}}\right)=\frac{G \times C}{100 \times V}
$$

where $\mathrm{G}$ is the amount of solution absorbed by wood or bamboo that is calculated by $\mathrm{T}_{2}-\mathrm{T}_{1}$; where $\mathrm{T}_{2}$ is weight of wood or bamboo after impregnation $(\mathrm{kg})$ and $\mathrm{T}_{1}$ is weight of wood or bamboo before impregnation $(\mathrm{kg}), \mathrm{C}$ is solution concentration as percentage, and $\mathrm{V}$ is the volume of the sample $\left(\mathrm{m}^{3}\right)$.

\section{Accelerated weathering test procedure}

The accelerated weathering experiment was performed in a QUV weathering tester with eight UVA 340 lamps according to Cycle 1 in ASTM G154 (2012) standard. The weathering schedule involves a continuous light irradiation of $8 \mathrm{~h}$ following with a condensation for $4 \mathrm{~h}$. Samples were exposed to accelerated weathering for $168 \mathrm{~h}, 336 \mathrm{~h}, 504 \mathrm{~h}$ and $672 \mathrm{~h}$. The average irradiance was $0,89 \mathrm{~W} / \mathrm{m}^{2} / \mathrm{nm}$ at $340 \mathrm{~nm}$ wavelengths. The temperature of the light irradiation period and the condensation period was $60^{\circ} \mathrm{C}$ and $50^{\circ} \mathrm{C}$, respectively.

\section{Color test}

The color parameters $a^{*}, b^{*}$, and $L^{*}$ were determined with a X-Rite SP Series Spectrophotometer. The color coordinates were measured on the surface of samples at the same five points before and after accelerated weathering. $\Delta L^{*}, \Delta a^{*}$ and $\Delta b^{*}$ were calculated based on the color coordinates before and after accelerated weathering. The total color difference $\left(\Delta E^{*}\right)$ was determined for each treatment group as follows:

$$
\begin{aligned}
& \Delta a^{*}=a_{f}^{*}-a_{i}^{*} \\
& \Delta b^{*}=b_{f}^{*}-b_{i}^{*} \\
& \Delta L^{*}=L_{f}^{*}-L_{i}^{*} \\
& \left(\Delta E^{*}\right)=\left[\left(\Delta a^{*}\right)^{2}+\left(\Delta b^{*}\right)^{2}+\left(\Delta L^{*}\right)^{2}\right]^{1 / 2}
\end{aligned}
$$

where $\Delta a^{*}, \Delta b^{*}$, and $\Delta L^{*}$ are the changes between the initial and final interval values.

\section{Gloss test}

The gloss of samples was determined using a BYK Gardner, Micro-TRI-Glossmeter at the same five points on the surface before and after accelerated weathering. Gloss test was performed according to ASTM D523-08 (2008). The chosen geometry was an incidence angle of $60^{\circ}$. Results were based on a specular gloss value of 100 , which relates to the perfect condition under identical illuminating and viewing conditions of a highly polished, plane, black glass surface.

\section{Surface roughness test}

The Mitutoyo Surftest SJ-301 instrument was employed for surface roughness measurements according to DIN 4768 (1990). Surface roughness parameter $(R z)$ is an arithmetic mean of the 10-point height of irregularities. Four measurements were recorded at the same points on the surface of the each sample before and after accelerated weathering. 


\section{Statistical test}

Surface roughness, gloss and color changes of impregnated samples and control (un-impregnated) samples before and after accelerated weathering were statistically tested by One-Way Anova test using SPSS 18.0 program. The significance $(P<0,05)$ found in Anova test between the treatments was compared with Duncan homogeneity groups.

\section{RESULTS AND DISCUSSION}

\section{Retention of preservatives in Scots pine and bamboo samples}

Retention values were found to be $4,63-4,88 \mathrm{~kg} / \mathrm{m}^{3}$ and $14,61-16,32 \mathrm{~kg} / \mathrm{m}^{3}$ for bamboo and Scots pine samples, respectively (Table 1). There was no evidence for a difference between the retention values of bamboo samples impregnated with the various preservatives $(P>0,05$; One-Way Anova). Wahab et al. (2007) found retention of bamboo samples as $4,54-6,45 \mathrm{~kg} / \mathrm{m}^{3} ; 4,93-7,74 \mathrm{~kg} / \mathrm{m}^{3}$ and $4,41-6,30 \mathrm{~kg} / \mathrm{m}^{3}$ for $2 \%$ solution of ACQ, CCA and BBA treatment with vacuum, respectively. Lee et al. (2001) found CCA retention of bamboo culms reached only $22 \%$ of the target retention, and they reported penetration of bamboo was difficult than penetration of pine under same treatment conditions. Retention values of bamboo samples were lower than those of Scots pine samples. Bamboo has different structure than wood has, and it lacks radial transport systems which has a significant influence on the preservative treatments (Sun et al. 2012).

Table 1. Retention $\left(R\right.$ in $\mathrm{kg} / \mathrm{m}^{3}$ ) of bamboo (Phyllostachys bambusoides) and Scots pine (Pinus sylvestris) samples

\begin{tabular}{|l|l|l|}
\hline Wood preservatives & Bamboo & Scots pine \\
\hline TAN-E & $4,78^{\mathrm{a}}(0,56)$ & $14,61^{\mathrm{b}}(0,46)$ \\
\hline ACQ & $4,83^{\mathrm{a}}(0,45)$ & $15,75^{\mathrm{ab}}(0,76)$ \\
\hline CCB & $4,88^{\mathrm{a}}(0,76)$ & $16,32^{\mathrm{a}}(0,47)$ \\
\hline BB & $4,63^{\mathrm{a}}(0,56)$ & $15,35^{\mathrm{ab}}(0,71)$ \\
\hline
\end{tabular}

(Values in parenthesis are standard deviations and different letters indicate significant difference by Duncan's homogeneity test $(P<0,05)$.

\section{Color changes of samples}

Figures 1 and 2 indicate color changes of bamboo and Scots pine samples $\left(\Delta a^{*}, \Delta b^{*}, \Delta L^{*}\right.$, and $\left.\Delta E^{*}\right)$ accelerated weathering from $168 \mathrm{~h}$ to $672 \mathrm{~h}$, respectively. 

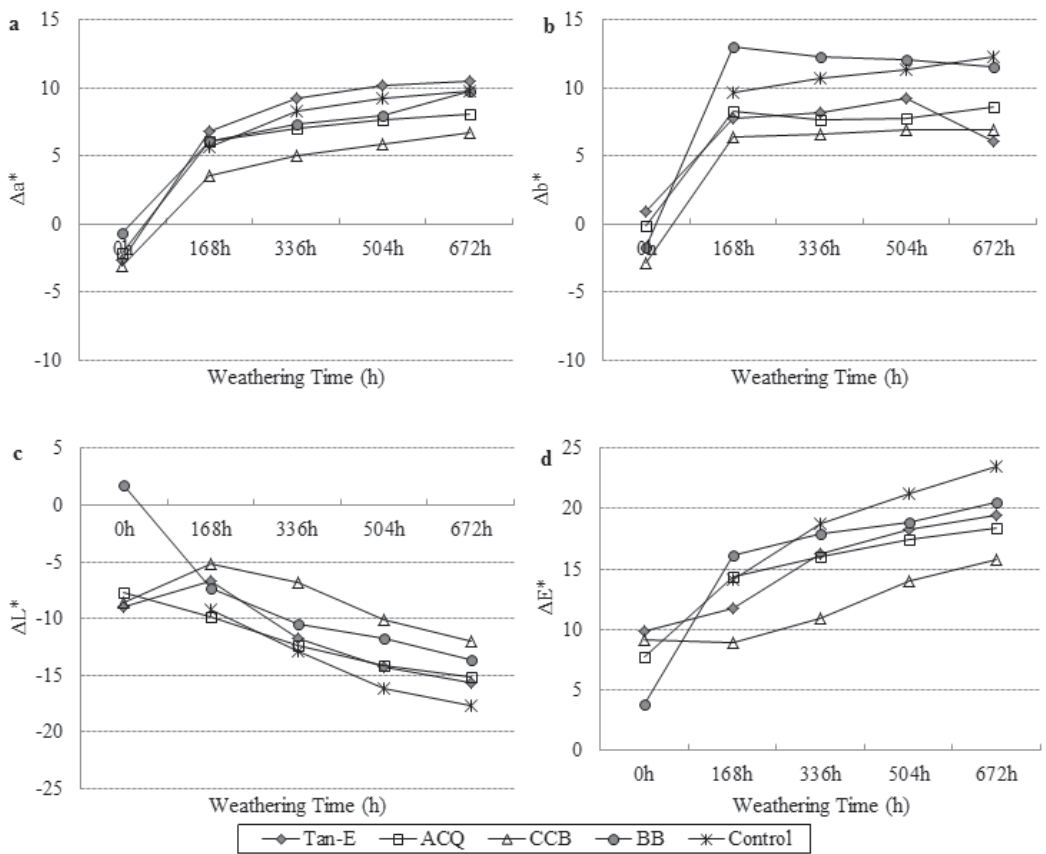

Figure 1. Color parameters of bamboo samples accelerated weathering a: Changes in $\Delta a^{*}$; b: Changes in $\Delta b^{*}$; c: Changes in $\Delta L^{*}$; d: Total color changes $\left(\Delta E^{*}\right)$.
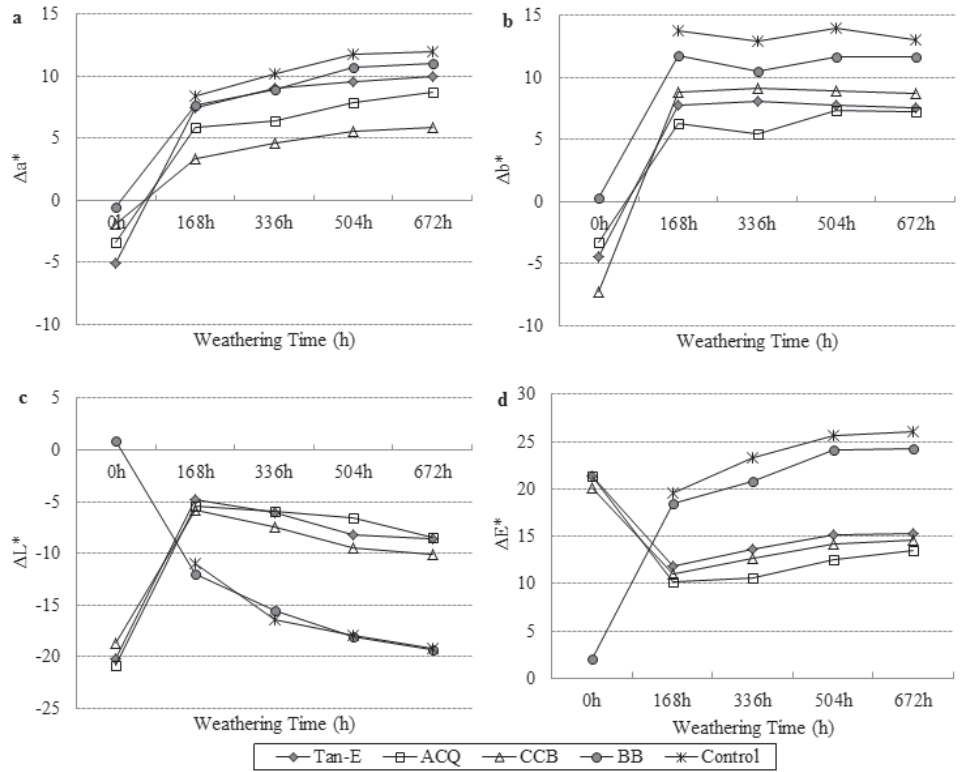

Figure 2. Color parameters of Scots pine samples accelerated weathering a: Changes in $\Delta a^{*}$; b: Changes in $\Delta b^{*}$; c: Changes in $\Delta L^{*}$; d: Total color changes $\left(\Delta E^{*}\right)$. 
Surface of bamboo and Scots pine samples had a dark, reddish and yellowish color after accelerated weathering (Figures 1a, 1b, 1c, 2a, 2b, 2c). Reddish and yellowish surfaces of bamboo after accelerated weathering are in consentient with the surfaces of bamboo exposed to natural weathering (Kim et al. 2008), and to photo-irradiation (Wang and Ren 2008). Dark color as indicated by the negative $\Delta L^{*}$ values with the exposure period were also recorded by Wang and Ren (2008) and Qin and Yu (2009). The increase in the chromaticity coordinate $\left(\Delta a^{*}\right.$ and $\left.\Delta b^{*}\right)$ may be explained by the changes of some chromophoric groups of lignin (Grelier et al. 2000). The highest dark, yellowish and reddish surface color based on the initial stage was seen during the first accelerated weathering period $(168 \mathrm{~h})$. CCB showed the least change in $\Delta a^{*}$ and $\Delta L^{*}$ values during all accelerated weathering periods while CCB, ACQ and Tan-E showed similar effect on stabilization of the surfaces to become yellowish for bamboo samples. The stabilization effect of copper based preservatives on $\Delta a^{*}, \Delta b^{*}$ and $\Delta L^{*}$ values was much more clear for Scots pine samples than for bamboo samples after accelerated weathering. This may be due to low retention levels of preservatives in bamboo samples. The least reddish surfaces for Scots pine were recorded in the following order: CCB, ACQ and Tan-E impregnation. The lowest $\Delta b^{*}$ values for Scots pine samples were recorded in the following order: ACQ, Tan-E and CCB treatments. BB impregnated samples showed similar performance as the control samples against reddish and yellowish color change since BB impregnation did not have protection effect against color change. According to Duncan homogeneity groups in One-Way Anova Test $(P<0,05)$ for $\Delta L^{*}$ values of Scots pine, copper based preservatives showed greater stability than boron compounds did, and copper based preservatives showed similar efficiency on $\Delta L^{*}$ values. A darker surface in control samples than in copper based preservative impregnated samples was probably related to copper based preservative impregnation enhanced the stabilization of wood color in the visible region by reducing the lignin degradation resulting from UV light (Grelier et al. 2000).

Total color change of bamboo samples increased with the increase in accelerated weathering period. Wood discoloration is thought to be related with the formation of colored unsaturated carbonyl compounds (quinones) since photochemical reactions of lignin occur (Wang and Ren 2008). CCB treatment showed to be best preservative to stabilize color of bamboo against accelerated weathering factors in this study. Chromium and copper in CCB formulation might create synergistic effect to retard the surface degradation during accelerated weathering. The color stability of the bamboo samples after $672 \mathrm{~h}$ of accelerated weathering was in the following order: CCB $\geq$ ACQ $\geq$ Tan-E $\geq \mathrm{BB} \geq$ Control (Duncan homogeneity groups; $P<0,05$; One-Way Anova). Copper based preservatives showed similar efficiency on stabilizing color for Scots pine samples at $672 \mathrm{~h}$ of accelerated weathering. Copper forms some complexes with wood components (Grelier et al. 2000) such as copper-cellulose complexes, copper-lignin complexes and crystalline or amorphous inorganic/organic copper compounds (Temiz et al. 2005), and wood ion complexes formed at the wood surfaces possibly provide resistance to wood surface by blocking the free phenolic groups, which are the reactive sites of photochemical reactions (Grelier et al. 2000). 


\section{Gloss of samples}

Table 2 indicates gloss values of samples after impregnation and accelerated weathering.

Table 2. Gloss of samples.

\begin{tabular}{|c|c|c|c|c|c|c|}
\hline \multirow{2}{*}{\multicolumn{2}{|c|}{ Groups }} & \multirow{3}{*}{$\begin{array}{c}\text { Before } \\
\text { weathering } \\
1,66^{\mathrm{b}}(0,05)\end{array}$} & \multicolumn{4}{|c|}{ After weathering } \\
\hline & & & \multirow{2}{*}{$\frac{168 \mathrm{~h}}{1,56^{\mathrm{bc}}(0,15)}$} & \multirow{2}{*}{$\frac{336 \mathrm{~h}}{1,46^{\mathrm{b}}(0,18)}$} & \multirow{2}{*}{$\frac{504 \mathrm{~h}}{1,40^{\mathrm{c}}(0,18)}$} & \multirow{2}{*}{$\frac{672 \mathrm{~h}}{1,35^{\mathrm{c}}(0,19)}$} \\
\hline \multirow{5}{*}{$\begin{array}{c}\text { Bamboo } \\
\text { (Phyllostachys } \\
\text { bambusoides) }\end{array}$} & Tan-E & & & & & \\
\hline & ACQ & $1,73^{\mathrm{b}}(0,18)$ & $1,45^{\mathrm{c}}(0,19)$ & $1,45^{\mathrm{b}}(0,23)$ & $1,42^{\mathrm{c}}(0,24)$ & $1,36^{\mathrm{c}}(0,17)$ \\
\hline & $\mathrm{CCB}$ & $2,03^{\mathrm{ab}}(0,73)$ & $2,03^{\text {bcd }}(0,93)$ & $1,90^{\mathrm{ab}}(0,61)$ & $1,82^{\mathrm{b}}(0,44)$ & $1,72^{\mathrm{b}}(0,25)$ \\
\hline & BB & $2,37^{\mathrm{a}}(0,5)$ & $2,32^{\mathrm{c}}(0,40)$ & $2,27^{\mathrm{a}}(0,40)$ & $2,25^{\mathrm{a}}(0,29)$ & $2,18^{\mathrm{a}}(0,31)$ \\
\hline & Control & $2,43^{\mathrm{a}}(0,3)$ & $2,10^{\mathrm{bc}}(0,15)$ & $2,03^{\mathrm{a}}(0,15)$ & $1,95^{\mathrm{ab}}(0,14)$ & $1,93^{\mathrm{ab}}(0,08)$ \\
\hline \multirow{5}{*}{$\begin{array}{l}\text { Scots pine } \\
\quad(\text { Pinus } \\
\text { sylvestris) }\end{array}$} & Tan-E & $3,53^{\mathrm{b}}(0,40)$ & $3,57^{\mathrm{a}}(0,35)$ & $3,97^{\mathrm{a}}(0,42)$ & $4,13^{\mathrm{a}}(0,46)$ & $4,33^{\mathrm{a}}(0,31)$ \\
\hline & ACQ & $3,33^{\mathrm{b}}(0,55)$ & $3,53^{\mathrm{a}}(0,75)$ & $3,77^{\mathrm{a}}(0,67)$ & $4,13^{\mathrm{a}}(0,75)$ & $4,30^{\mathrm{a}}(1,13)$ \\
\hline & $\mathrm{CCB}$ & $2,47^{\mathrm{c}}(0,06)$ & $2,30^{\mathrm{b}}(0,10)$ & $2,47^{\mathrm{b}}(0,25)$ & $2,57^{\mathrm{b}}(0,21)$ & $2,70^{\mathrm{b}}(0,17)$ \\
\hline & $\mathrm{BB}$ & $4,00^{\mathrm{b}}(0,56)$ & $3,93^{\mathrm{a}}(0,64)$ & $4,07^{\mathrm{a}}(0,80)$ & $4,17^{\mathrm{a}}(0,91)$ & $4,47^{\mathrm{a}}(1,16)$ \\
\hline & Control & $4,80^{\mathrm{a}}(0,36)$ & $4,30^{\mathrm{a}}(0,26)$ & $4,27^{\mathrm{a}}(0,31)$ & $4,03^{\mathrm{a}}(0,40)$ & $3,97^{\mathrm{ab}}(0,25)$ \\
\hline
\end{tabular}

(Values in parenthesis are standard deviations and different letters indicate significant difference by Duncan's homogeneity test $(P<0,05)$

Gloss of both Scots pine and bamboo samples decreased with the impregnation process. Ozdemir et al. (2015) reported that water-based wood preservatives increase surface porosity and raised fibres decrease gloss value. The results showed that gloss values of Scots pine were higher than bamboo samples for control and impregnated samples. The preservatives distributed on the bamboo surfaces and bamboo's itself might cause low gloss property. Baysal (2012) reported that CCA impregnation limited the glossiness to a point in Scots pine before the exposure, possibly owing to the absorption and dispersion of the reflected rays by salt crystals prominent in the large lumens of the tracheid in the wide early wood sections of the grains. The results in this study are in good agreement with this researcher's findings.

Gloss of both impregnated and control bamboo samples slightly decreased with the increase in accelerated weathering periods. The highest gloss of bamboo samples was obtained with BB treatment while the lowest gloss was obtained with ACQ and Tan-E impregnations after accelerated weathering. This effect was statistically proven by One-Way Anova Test. Opposite to findings in bamboo samples, gloss of Scots pine samples impregnated with the preservatives increased with longer accelerated weathering periods while gloss of Scots pine control samples decreased. Light absorption of chemicals may be the reason for this observation.

\section{Surface roughness of samples}

Table 3 shows surface roughness of both Scots pine and bamboo samples after impregnation and accelerated weathering from $168 \mathrm{~h}$ to $672 \mathrm{~h}$. Copper based preservative treatments increased surface roughness of bamboo samples while BB treatment decreased the surface roughness. In the case of Scots pine, all treatments increased surface roughness. Aydin and Colakoglu (2005) found slight changes on surface roughness of veneers treated with borax, boric acid and ammonium acetate solutions. Ayrilmis et al. (2006) reported that high concentration of various fire retardants caused rougher surfaces of plywood than the lower concentrations. Surface of CCA treated wood was also rougher than that of control wood (Maldas and Kamdem 1998). In generally the results showed that rougher surfaces were obtained within bamboo samples than Scots pine samples after impregnation. 
Table 3. Surface roughness of samples.

\begin{tabular}{|c|c|c|c|c|c|c|}
\hline \multirow{2}{*}{\multicolumn{2}{|c|}{ Groups }} & \multirow{2}{*}{$\begin{array}{c}\text { Before } \\
\text { weathering }\end{array}$} & \multicolumn{4}{|c|}{ After weathering } \\
\hline & & & $168 \mathrm{~h}$ & $336 \mathrm{~h}$ & $504 \mathrm{~h}$ & $672 \mathrm{~h}$ \\
\hline \multirow{5}{*}{$\begin{array}{c}\text { Bamboo } \\
\text { (Phyllostachys } \\
\text { bambusoides) }\end{array}$} & Tan-E & $35,29^{\mathrm{a}}(7,43)$ & $38,14^{\mathrm{a}}(11,20)$ & $38,93^{\mathrm{a}}(5,40)$ & $36,83^{\mathrm{ab}}(4,56)$ & $39,43^{\mathrm{a}}(5,87)$ \\
\hline & ACQ & $35,30^{\mathrm{a}}(2,17)$ & $40,96^{\mathrm{a}}(3,71)$ & $41,87^{\mathrm{a}}(7,53)$ & $41,18^{\mathrm{a}}(5,39)$ & $36,43^{\mathrm{a}}(3,76)$ \\
\hline & $\mathrm{CCB}$ & $35,12^{\mathrm{a}}(7,82)$ & $32,43^{\mathrm{ab}}(6,72)$ & $32,18^{\mathrm{ab}}(7,38)$ & $31,04^{\mathrm{bc}}(6,54)$ & $32,50^{\text {a }}(7,38)$ \\
\hline & $\mathrm{BB}$ & $21,95^{\mathrm{b}}(5,97)$ & $31,69^{\mathrm{ab}}(4,05)$ & $32,90^{\mathrm{ab}}(7,23)$ & $32,96^{\mathrm{abc}}(8,78)$ & $32,50^{\mathrm{a}}(8,22)$ \\
\hline & Control & $26,89^{\mathrm{ab}}(5,28)$ & $24,20^{\mathrm{b}}(1,89)$ & $25,69^{\mathrm{b}}(3,38)$ & $25,73^{\mathrm{c}}(2,88)$ & $28,31^{\mathrm{a}}(4,16)$ \\
\hline \multirow{5}{*}{$\begin{array}{l}\text { Scots pine } \\
\quad \text { (Pinus } \\
\text { sylvestris) }\end{array}$} & Tan-E & $30,74^{\mathrm{a}}(1,41)$ & $23,57^{\mathrm{ab}}(4,80)$ & $25,63^{\mathrm{a}}(6,27)$ & $20,89^{\mathrm{a}}(8,11)$ & $21,43^{\mathrm{a}}(2,04)$ \\
\hline & ACQ & $32,83^{\mathrm{a}}(7,39)$ & $33,03^{\mathrm{a}}(7,30)$ & $23,03^{\mathrm{a}}(4,04)$ & $23,41^{\mathrm{a}}(0,28)$ & $28,84^{\mathrm{a}}(9,34)$ \\
\hline & $\mathrm{CCB}$ & $29,78^{\mathrm{a}}(9,40)$ & $18,32^{\mathrm{bc}}(1,12)$ & $21,86^{\mathrm{a}}(3,39)$ & $23,59^{\mathrm{a}}(4,44)$ & $27,72^{\text {a }}(9,98)$ \\
\hline & $\mathrm{BB}$ & $29,37^{\mathrm{a}}(4,33)$ & $25,26^{\mathrm{ab}}(1,15)$ & $21,15^{\mathrm{a}}(3,10)$ & $23,72^{\mathrm{a}}(4,42)$ & $22,03^{\mathrm{a}}(2,71)$ \\
\hline & Control & $8,19^{\mathrm{b}}(1,30)$ & $9,32^{\mathrm{c}}(3,16)$ & $11,08^{\mathrm{b}}(3,98)$ & $9,95^{\mathrm{b}}(1,51)$ & $12,86^{\mathrm{b}}(6,29)$ \\
\hline
\end{tabular}

(Values in parenthesis are standard deviations and different letters indicate significant difference by Duncan's homogeneity test $(P<0,05)$

Bamboo surfaces generally became rougher with the increase in accelerated weathering period compared to initial surface roughness values. During the accelerated weathering period of $672 \mathrm{~h}$, surface roughness decreased for CCB impregnated bamboo samples. Surface of BB impregnated bamboo samples became rougher in the first weathering period $(168 \mathrm{~h})$, but afterwards the surface roughness did not change too much, nearly stayed stable. Tanalith-E impregnation caused rougher bamboo surfaces compared to other preservatives. During the accelerated weathering periods of 168 $\mathrm{h}, 336 \mathrm{~h}$ and $504 \mathrm{~h}$, some differences were obtained between the impregnated and control bamboo samples, that generally high surface roughness were observed in impregnated samples. However, at the end of $672 \mathrm{~h}$ of accelerated weathering, all groups showed similar surface roughness $(P>0,05$; One-Way Anova). This finding also demonstrated that copper based preservatives were effective for ensuring the surface quality of bamboo over time. Considering the general behavior of preservatives on surface roughness of bamboo samples after accelerated weathering, CCB treatment seemed to ensure more smooth surfaces than other preservatives after accelerated weathering. Scots pine control samples showed rougher surfaces with the increase in accelerated weathering period however impregnated wood surfaces showed smoother surfaces than the initial surfaces. After $672 \mathrm{~h}$ of accelerated weathering period, wood preservatives performed similar efficiency on roughness. The results showed that bamboo samples showed rougher surfaces than Scots pine samples after accelerated weathering. Anatomical differences between the bamboo and wood make them quite different in surface structure, roughness and density (Wang and Ren 2008, 2009). 


\section{CONCLUSIONS}

This study dealt with the color, surface roughness and gloss changes of bamboo and Scots pine samples impregnated with boron and copper based preservatives after accelerated weathering. Related to bamboo's anatomical properties, retention of preservatives was relatively lower than that of Scots pine samples. Pressure application in impregnation process could be recommended to obtain higher retentions for bamboo samples. BB treatment did not show a protection effect against accelerated weathering. The best preservative for bamboo seemed to be CCB against color changes and obtaining smooth surfaces after accelerated weathering. In the case of Scots pine samples, all copper based preservatives ensured equal stability against color changes. Bamboo control samples showed greater efficiency against color changes than Scots pine control samples did while impregnated samples conversely behaved probable due to the different levels of absorbed amount of preservatives in Scots pine and bamboo. In general, bamboo samples did not show any advantages over Scots pine samples. Impregnated wood samples exhibited greater gloss, smooth surfaces and color stability than impregnated bamboo samples.

\section{ACKNOWLEDGMENTS}

The authors would like to thank Prof. Dr. Mustafa Var for providing the bamboos in the Department of Landscape Architecture, KTU, Turkey, and undergraduate student Saban Kart for color, surface roughness and gloss measurements in the Department of Wood Science and Technology, Mugla Sitki Kocman University, Turkey.

\section{REFERENCES}

ASTM D523-08. 2008. Standard test method for specular gloss (West Conshohocken: 2008).

ASTM G 154. 2012. Standard Practice for Operating Fluorescent Ultraviolet (UV) Lamp Apparatus for Exposure of Nonmetallic Materials.

Aydin, I.; Colakoglu, G. 2005. Effects of surface inactivation, high temperature drying and preservative treatment on surface roughness and colour of alder and beech wood. Appl Surf Sci 252(2): 430-440.

Ayrilmis, N.; Korkut, S.; Tanritanir, E.; Winandy J.E.; Hiziroglu, S. 2006. Effect of various fire retardants on surface roughness of plywood. Build Environ 41(7):887-892.

Baysal, E. 2012. Surface characteristics of CCA treated Scots pine after accelerated weathering. Wood Research 57(3):375-382. 
Cornfield, J.A.; Hale, M.; Fellis, G. 1994. A comparison of analytical and visual techniques used for assessment of weathering properties of chromium and copper azole treated timber. In: International Research Group on Wood Preservation. IRG/WP/20023.

de Melo, R.R.; Stangerlin, D.M.; Campomanes Santana, R.R.; Pedrosa, T.D. 2015. Decay and termite resistance of particleboard manufactured from wood, bamboo and rice husk. Maderas.Ciencia y Tecnología 17(1): 55-62.

Denes, A.R.; Young, R.A. 1999. Reduction of weathering degradation of wood through plasmapolymer coating. Holzforschung 53(6): 632-640.

DIN 4768-1990. 1990. Determination of values of surface roughness parameters Ra, Rz, Rmax using electrical contact (stylus) instruments. Concepts and measuring conditions. Berlin, Germany.

Evans, P.; Chowdhury, J.M.; Mathews, B. 2005. Weathering and surface protection of wood, In: Kutz M. (ed) Handbook of Environmental Degradation of Materials. William Andrew Inc, New York, $277 \mathrm{p}$.

Feist, W.C.; Hon, D.N.S. 1984. Chemistry of Weathering and Protection, In: Rowell RM (ed), The Chemistry of Solid Wood, American Chemical Society, Washington DC.

Feist, W.C.; Williams, R.S. 1991. Weathering durability of chromium-treated southern pine. Forest Prod J 41(1): 8-14.

Freeman, M.H.; Mcintyre, C.R. 2008. A comprehensive review of copper based wood: with a focus on new micronized or dispersed copper systems. Forest Prod $J$ 58: 6-27.

Grelier, S.; Castellan, A.; Kamdem, D.P. 2000. Photo-protection of copper amine treated wood. Wood Fiber Sci 32:196-202.

Jiang, M. 2008. Field trial of copper treated moso bamboo in Southern China. In: International Research Group on Wood Preservation. IRG/WP 08-30455.

Jin, L.;Archer, K.; Preston, A. 1991. Surface characteristics of wood treated with various AAC, ACQ and CCA formulations after weathering. In: International Research Group on Wood Preservation. IRG/WP/2369.

Kim, J.S.; Lee, K.H.; Cha, M.Y.; Kim, Y.S. 2008. Anatomical, physical and chemical changes of bamboo (Phyllostachys puberscence) during weathering processes. In: International Research Group on Wood Preservation. IRG/WP 08-10650.

Kumar, S. 2007. Bamboo protection research: Contributions from India. In: International Research Group on Wood Preservation. IRG/WP 07-40355.

Lee, A.W.C.; Chen, G.; Tainter, F.H. 2001. Comparative treatability of Moso bamboo and Southern pine with CCA preservative using a commercial schedule. Bioresour Technol 77: 87-88.

Leithoff, H.; Peek, R.D. 2001. Heat treatment of bamboo. In: International Research Group on Wood Preservation. IRG/WP 01-40216. 
Lifang, C.; Haitao, S.; Yanjun, Z. 2010. The natural durability and preservative treatability of 11 bamboo species. In: International Research Group on Wood Preservation. IRG/WP 10-10708.

Maldas, D.C.; Kamdem, D.P. 1998. Surface characterization of chromated copper arsenate (CCA)-treated red maple. J Adhes Sci Technol 12(7): 763-772.

Manalo, R.D.; Garcia, C.M. 2012. Termite resistance of thermally-modified Dendrocalamus asper (Schultes f.) Backer ex Heyne. Insects 3: 390-395.

Nejad, M.; Cooper, P. 2011. Exterior wood coatings, Part-1: Performance of semitransparent stains on preservative-treated wood. J Coat Technol Res 8(4): 449-458.

Ozdemir, T.; Temiz, A.; Aydin, I. 2015. Effect of Wood Preservatives on Surface Properties of Coated Wood. Advances in Materials Science and Engineering. http://dx.doi.org/10.1155/2015/631835.

Qin, L.; Yu, W.J. 2009. Research on surface color, properties of thermo-treated reconstituted bamboo lumber after artificial weathering test. Adv Mat Res 79(82): 1395-1398.

Salim, R.; Wahab, R.; Ashaari, Z. 2008. Effect of oil heat treatment on chemical constituents of semantan bamboo (Gigantochloa scortechinii Gamble). J Sustainable Dev 1(2): 91-98.

Sun, F.; Bao, B.; Ma, L.; Chen, A.; Duan, X. 2012. Mould-resistance of bamboo treated with the compound of chitosan-copper complex and organic fungicides. J Wood Sci 58: 51-56.

Temiz, A.; Yildiz, U.C.; Aydin, I.; Eikenes, M.; Alfredsen, G.; Colakoglu, G. 2005. Surface roughness and color characteristics of wood treated with preservatives after accelerated weathering test. Appl Surf Sci 250: 35-42.

Temiz, A.; Alfredsen, G.; Yildiz, U.C.; Gezer, E.D.; Kose, G.; Akbas, S.; Yildiz, S. 2014. Leaching and decay resistance of alder and pine wood treated with copper based wood preservatives. Maderas. Ciencia y Tecnología 16: 63-76.

Tomak, E.D.; Topaloglu, E.; AY, N.; Yildiz, U.C. 2012. Effect of accelerated aging on some physical and mechanical properties of bamboo. Wood Sci Technol 46: 905-918.

Wahab, R.; Mustapa, M.T.; Sudin, M.; Moktar, J. 2007. Durability Assessment of Preservatives Treated Bambusa vulgaris in Unsterile Soil Burial Tests. Res J Microbiology 2: 504-508.

Wahab, R.; Sudin, M.; Mustapa, T.; Yunus, A.A.M. 2010. Durability performance of Gigantochloa scortechinii through laboratory fungal decay tests. Res J Microbiology 5(5): 478-482.

Wang, X.Q.; Ren, H.Q. 2008. Comparative study of the photo-discoloration of moso bamboo (Phyllostachys pubescens Mazel) and two wood species. Appl Surf Sci 254: 7029-7034.

Wang, X.Q.; Ren, H.Q. 2009. Surface deterioration of moso bamboo (Phyllostachys pubescens) induced by exposure to artificial sunlight. $J$ Wood Sci 55(1): 47-52.

Williams, R.S. 2005. Weathering of wood, In: Rowell RM (ed). Handbook of Wood Chemistry and Wood Composites. CRC Press, Florida, 139 p. 
Yalinkilic, M.K.; Ilhan, R.; Imamura, Y. 1999. Weathering durability of CCB-impregnated wood for clear varnish coatings. $J$ Wood Sci 45: 502-514.

Zhang, J.; Kamdem, P.D. 2000. Weathering of copper-amine treated wood. In: International Research Group on Wood Preservation. IRG/WP 00-40155. 